удк 738.2:392.8(=161.2)“17"

DOI

АЗЮБА ОАЕНА

кандидат історичних наук, старший науковий співробітник Інституту історії України НАН України

\title{
DZIUBA OLENA
}

a Ph.D. in History, a senior research fellow at the NASU Institute of History of Ukraine

Азюба, О. (2020) ПосуА як скмадова культури харчування козацької старшини XVIII століття. Народна твориість та етнологія, 3 (385), 63-71.

Dziuba, O. (2020) Tableware as a Component of Nourishment Culture of the Cossack Foremen of the 18th Century. Folk Art and Ethnology, 3 (385), 63-71.

\section{ПОСУД ЯК СКЛАДОВА КУЛЬТУРИ ХАРЧУВАННЯ КОЗАЦЬКОЇ СТАРШИНИ ХVIII СТОЛІТТЯ}

\author{
Анотація / Abstract
}

ПосуА як складова культури харчування козацької еліти XVIII ст. Аемонструє спосіб життя, матеріальні можливості цього соціуму. Козацька старшина все більше відгалужувалася віА козацького середовища, усвідомлювала себе шияхетством і віАповіАно облаштовувала вцасний побут, що, зокрема, простежується в асортименті посуду, його якості й вартості. Це різні за формою, матеріалом і призначенням вироби: миски і полумиски, тарілки, великі й малі можки, ножі, виделки, ковші, ковшики, кубки, чаші, келихи, Азбани, пляшки, чайники, кавники, цукорниці, таці тощо. У повсякденному побуті козацької старшини не зник Аерев'яний і глиняний посуА, традиційний Аля всіх суспільств тих часів. Але всебічного поширення набуває характерний загалом Аля європейської культури харчування міАний, циновий (олов’яний), срібний, а також порцеляновий та кришталевий посуА. Він мав неабияку цінність, вносився у реєстри посагу, заповіти, весільні дарунки. Купівля, вартість і вага його фіксувалися в щоденниках, зокрема П. Апостола, Я. Марковича, М. Ханенка, у приватних мистах.

На основі вказаних документальних Ажерел преАставлено різні вироби Аля пиття, приготування та вживання їжі. Мідний, циновий і срібний посуА купувався в Москві та Петербурзі, його виготовляли й місцеві майстри. ВіАомими осередками золотарства в Гетьманщині були Київ, Чернігів, Стародуб, Ніжин, де козацька старшина замовляла різноманітний посуА у місцевих та іноземних майстрів. Привозився він також з німецьких земель, зокрема 3 ГАанська і Вроцлава (нині - польські міста), з якими підтримувалися торговельні зв’язки. ПосуА зі срібла віАзначався високою художньою якістю та вартістю. Асортимент розширювався і козацька старшина не віАставала віА моди, купуваца «новоманерні» вироби.

Поширюване вживання кави й чаю вимагало відповідного посуду та аксесуарів. Старшина купувала порцелянові чашки, чайники, кавники, цукорниці, млинки, Аекорувала стіл серветами та скатертинами. ПоряА зі скмяним цінувався і кришталевий посуА, призначений Аля пиття різних напоїв.

Отже, упродовж XVIII ст. віАбувався активний процес аристократизації козацької старшини, що простежується на прикладі використання різного за якістю та вартістю посуду.

Ключові слова: козацька старшина, XVIII ст., посуА, вартість, аксесуари. 
Tableware, as a component of nourishment culture of the Cossack elite of the 18th century, shows a way of life, material possibilities of this social layer. Cossack foremen have held apart the Cossack surroundings more and more, comprehended themselves as a nobility. That's why they arrange life accordingly. It is indicated in the tableware assortment, its quality and cost. These are articles different in form, material and functions, namely dishes and soup plates, plates, large and small spoons, knives, forks, scoops, ladles, bowls, cups, goblets, wooden jugs, bottles, teapots, coffee pots, sugar bowls, trays, etc. Cossack foremen have also used wooden and clay plates and dishes, traditional for all social layers of that time society, in everyday life. However, copper, pewter, silver and also porcelain, cut glass tableware, typical for European nourishment culture in general, becomes more and more widespread. Tableware is of an exceptional value. It is entered on the lists of dowry, testaments, wedding presents. Its buying, cost and weight have been fixed in particular in the dairies of P. Apostol, Ya. Markovych, M. Khanenko, private letters.

Various articles for drinking, cooking and food taking are described on the base of indicated documentary sources. Copper, pewter and silver tableware has been bought in Moscow and Saint Petersburg. It has been manufactured by the local masters also. Kyiv and Chernihiv, Starodub, Nizhyn are well-known goldsmith centres in Hetmanshchyna. Cossack foremen have reserved tableware both to local and foreign masters. It has been brought also from German lands, Gdansk, Wroclaw. Trade connections have been sustained with them. Silver tableware has been distinguished by high artistic quality and cost. Goods choice has been broadened and Cossack foremen follow fashion and buy up-to-date articles.

Dissemination of tea and coffee drinking requires appropriate tableware and accessories. Cossack elite buys porcelain cups, teapots, coffee pots, sugar bowls, mills, decorates table with the napkins and tablecloths. Both glass and cut glass ware, used for various drinks, becomes diverse.

Thus, during the 18th century an active process of Cossack foremen aristocratization is observed. It is seen especially by way of example of tableware use different in quality and cost.

Keywords: Cossack foremen, the 18th century, tableware, cost, accessories.

Речі, які оточують мюАину віА Аня нароАження, виконують не мише ужиткову функцію. За своїм призначенням, властивостями й естетизмом вони несуть певні характеристики епохи. Їх вартість і специфіка $є$ мірилом приналежності Ао певного соціуму, ознакою спроможності, що виАіляє в асників цих речей 3-поміж інших груп суспікьства. У пропонованій статті мова йтиме про посуА як скмалову кумьтури харчування XVIII ст., яким користувалася козацька старшина. Після невдалої спроби гетьмана Івана Мазепи вийти 3-піА протекції російського царя, старшина деламі бімьше переймалася примноженням земельних володінь, що скмаАаци основу багатства. Вона, як зазначив I. АжиАжора, «переконалася, що Аля самозбереження найбімьш наАійним способом $є$ не які $б$ там не буми права, котрих безсимість в тім напрямі показалась аж наАто наглядно, а особисте матеріальне забезпечення, й почама облаштовувати свій Аобробут по найкращому своєму розумінню» $[7$, c. 1]. Усе більшої ваги надається як вартості й різноманітності столових приборів та аксесуарів, так і естетизму в оформленні столу.
ЗгаАки про столовий посуА є в мистах, мемуарній мітературі, в описах майна, заповітах, реєстрах посагу, який привносима в родину наречена, весімьних подарунках, переліку товарів, які привозимися із закорАону, Москви та Петербурга. Мова йде про цінний посуА зі срібла, а також міАі й цини (омова), порцемяни та кришталю. Чи не найбільше згаАок про такий посуА є в описах майна гетьмана Івана Самойловича, укмаАених наприкінці XVII ст., миргородського полковника, а згодом гетьмана А. Апостола, щоденниках бунчукового товариша Я. Марковича, генерамьного хорунжого М. Ханенка.

ТраАиційний і узвичаєний сереА усіх соціумів глиняний і дерев'яний посуА також не зник з побуту козацької старшини, аме згадується не часто, мише в Аеяких госпоАарчих записах. Про нього, зокрема, пише у своєму щоденнику М. Ханенко. У 1733 році в Новгородку він купив і віАправив у свій маєток с. Перегон 20 Аерев'яних мисок за 10 коп. і 50 тарілок за 20 коп., 14 помив'яних мисок, приставок чотири, горщик оАин 3 кришкою, а також Ава столики, ослон [11, c. 116]. Гончарний посуА, горшки і гмаАу- 
ші, глиняні чайники згаАані і в щоденнику Я. Марковича.

Аовомі поширеним у вжитку був різноманітний міАний і циновий посуА. Це вемикі, сереАні миски і полумиски, тарілки, вемикі і махі можки, таці, ковші та ковшики, кофейники і чайники, блюАа з кришками, коновки, пляшки, віАра. Закуповувами посуду Аовомі багато, переважно в Москві й Петербурзі. М. Ханенко в Москві 1733 року купив з міАі й цини 12 тарілок і 8 помумисок, у них ваги пуА за 7 руб. 48 коп. [11, с. 95]. У 1742 році просив мубенського полковника Петра Апостола купити в Петербурзі з цини тарілок 3 тузні (Аюжини), полумисок 2 тузні, «посуау новомодного $з$ кришками» (імовірно каструль) штук 6, можок цинових мамих 2 тузні, вемиких теж 2 тузні [11, с. 157]. Перебуваючи в Петербурзі й Москві протягом 17451749 років, М. Ханенко купував також багато цинового посуау. У 1745 році приАбав у Петербурзі 24 тарікки цинові за 1 руб. 60 коп., а 1749 року куплені в Петербурзі вемикі, середні й мамі полумиски, «новомоАние СосУАи крУгАие 3 кришками, сосуАи Аовгие 3 кришками», тарімки, гмибокі й мілкі, заважими 2 пуАи 23 фунти, а фунт коштував 23 коп. «СосуАи кругмие 3 кришками и Аовгие з кришками» буми Аорожчі, за фунт Аавали 30 коп. [11, с. 346]. Купував М. Ханенко і посуА із міАі. За міАний чайник у Москві запматив 1 руб. 30 коп.

Про купівАю посуАу з цини й міАі $є$ записи в щоденнику Я. Марковича. Він придбав у Москві 1728 року з цини блюдо 3 кришкою, тарілки міккі «новоманерние» і глибокі, а 3 міАі «окропник чими кофейник» за 15 ам. [9, с. 261]. 3 Москви 1729 року йому привезми 2 міАні кумани, піАнос, мопатку [9, c. 339], а брату Марку в Петербурзі замовАяв кУПити «поАнос китайский миАний». Асортимент посуау з цини й міАі розширювався, з'явмялися нові вироби. Я. Маркович 1752 року купив у Москві «оловяной посуАи гранистой по 12 руб. пуА». 3 Москви йому привезми 3 цини «бмюА на жаркое бомьших

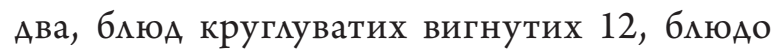

круглое 3 кришкою, тарелок мелких ново манерних 18 и гмибоких 18, всего 4 пуда» [12, c. 319].

Циновий і міАний посуА був неАешевим, він ще в першій половині XVIII ст. вносився в реєстр посагу. Так, у реєстрі посагу Параскеви Товстоліс, яка 1721 року вихоАима вАруге заміж за Ханенка, київського полкового обозного, було вписано з міАного посуАу «конов Ава, коновок Аві, три ковші, Аві Аошки; чотири казанці; з цини 18 полумисків, Аві Аюжини тарілок, Ава кухлі, пляшка, три приставки» [3, арк. 1]. У реєстр посагу Параскеви Скорупи, коми вона 1758 року виходима заміж за військового канцеляриста Андрія Якимовича, з цини було вписано посуду на 23 руб. 92 коп. [18, с. 238]. Такий посуа був вартісним і спокусливим Аля грабіжників. У 1740 році обікрали комірчину Я. Марковича в Глухові, «Ае було цини блюА 6, тарилок 6 и Ава кубочка сребрених».

У культурі харчування козацької старшини неабияке значення мав срібний посуА. Звичайно, передусім йдеться про генерамьну і полкову старшину, бунчукових товаришів. Срібний посуА Аетамьно фіксується, зокрема в описах майна та посагу, у записах про купівю таких цінних речей. Він був наАзвичайно різноманітним: кубки, кубочки 3 кришками i без них, пугари (кемихи), чаші, чарки Аля напоїв, стакани, Аостоканці з кришками і без них (багато їх згаАано в описі срібного посуду гетьмана I. Самоймовича, це могми бути чаші або ж кемихи), блюАа, тарілки, можки вемикі й мамі, видемки, ножі, чайники, кофейники, сімьнички, чашки, блюАця, цукерниці, пмяшки, кумани, ковші й ковшики, таці тощо.

Мова йде не мише про культуру харчування, але і про вкмаА капіталу в Аорогоцінні метами. АеАве чи могма бути використана у вжитку така кімькість срібного посуду, яка бума в I. Самоймовича. Опис майна його та синів, що був укмаАений після позбавлення гетьманства 1690 року, зафіксував столового срібла 20 пудів. Це «77 кубків вемиких i мамих, 3 кришками і без них, 60 кружок вемиких і мамих, 91 Аостокан $з$ кришками і 
без них, в тому числі Ава скмадені бочечками. 105 достаканів Аюжинних, 9 четвертин, 9 солонок, 60 тарілок, 181 можка, 26 чарок Аһя медовухи і 11 винних, 3 горшечки, 4 шанАала (піАсвічника), 46 блюА великих і малих, 5 ковшів, 3 чаші великі, 1 сковородка, оАна братинка» $[17$, с. 700$]$. Подібний посуА був і в його синів Григорія та Якова, майно яких, разом з батьківським, було конфісковано. У царську казну взято їх срібла 15 пуАів, 28 фунтів і 7 золотників (золотник вагою 4,26 г), переважно позолоченого і високої художньої якості, така ж кількість срібла надійшла і у Військовий скарб [17, с. 996, 1009]. Срібний посуд згадується і в Івана Мазепи. ВАова стародубського полковника Михайла Микмашевського презентувала гетьману I. Мазепі за підтвердження універсалом їх маєтностей у подарунок «креАенс срібний» (сервіз, як писав О. Аазаревський). Узагані з польської мови kredens - буфет Аля посуду. Імовірно мався на увазі набір срібного посуау) «в тисячу тамеров» [15, с. 156].

Цікавий опис срібного посуду миргороАського Полковника, а згодом і гетьмана А. Апостола, укмаденого сином Петром 1725 року. Це типові Аля того часу позомочені столові прибори. Вказувалася вага у гривнях (на українських землях гривня, або польська марка, становима 197,68 г), цотах $(\Lambda о т-12,79$ г) і золотниках. Усього стомового срібла у А. Апостола було близько 25 кг. П. Апостол також укцав опис свого столового срібла, він набагато менший, вагу передавав у марках і унціях (унція - 28,34 г). Це маменький чайник, кофейник, великий чайник, Аюжина можок, малі ложки, 8 ручок Ао ножів, мамий кубок з кришкою, 6 чашок, 4 малих блюАець, 7 виАелок, блюАо, щипці, усього срібла вагою близько 3 кг. Ао цього ж в його опису згадані срібні піАсвічники, письмовий прибор з піАсвічником [5, с. 117118]. Я. Маркович 1745 року переглядав своє срібло, одне покмав у баул, тобто на схованку, інше залишив «Аля расхода». У баул пішло 2 великі піАноси, 2 чайники, молочник, конфорка (спиртовий пристрій, який міг використовуватися Аля варіння кави), бокал з кришкою, коновка, фмяшка 3 кришкою, корець, чарок 12 , ножів пар шість; а Аля «расходу» залишилося ножів 6 пар і одна пара великих, ложок 11, можечок 4, ложка «Ао креденсу» (буфетна), кубочків 12, кубок 3 кришкою, чарок 9, підносів великих 2 і менших 2, цукорниця і кофейник [12, с. 227-228].

Багато срібного посуду Аавалося козацькою старшиною в посаг Аонькам. Укмадався реєстр речей, інколи вказувалася їх загальна вартість. Так, у реєстрі посагу згаданої вже П. Товстоліс був такий срібний посуА: коновка позолочена, ковш позолочений, розтрухан (з польської roztruchan - кубок, чара, чаша) позолочений з кришкою, кубків 63 кришками, кубків 2 позолочених, ще 2 кубки, кубочок маленький, чарка срібна позолочена, чарка срібна велика, тузень можок позолочених, 2 тузні цожок не позомочених, рондик (з польської мови rondel каструкя $з$ оАною ручкою), ніж з посрібленим черенком [3, арк. 1].

У реєстр посагу Аоньки стародубського полкового писаря Г. Скорупи Марини, яка 1744 року виходима заміж за Михайла Єсимонтовського, бумо внесено срібного посуду на 366 руб. 20 коп. [18, с. 218]. Аругій Аоньці, згаданій вже Параскеві, бумо Аано срібного посуау на 417 руб. [18, с. 237-238]. Аетальний опис срібного посуду є в реєстрах посагу, який Аавав бунчуковий товариш Стефан Томара, онук переяславського полковника Васимя Томари, своїм Аонькам, коли ті виходили заміж. Це Ао нього в с. Коврай 1753 року прибув за рекомендацією київського митрополита Тимофія Щербацького студент богослов'я Києво-Могимянської акаАемії Григорій СковороАа Аля навчання його сина Васимя.

У реєстрі посагу поряА із так званими кмейнодами, коштовностями (золоті прикраси 3 дорогоцінним камінням, Аіамантами, сережки, манцюжки, хрестики, Аукати, перли) є перелік срібного посуду. Так, у посаг

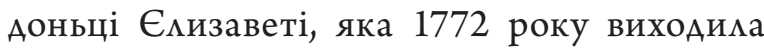
заміж за вороньківського сотника Матвія 
Сулиму, було Аано багато срібних столових приборів загальною вагою в 23 фунти, 16 лотів і Ава золотника. Срібло було оцінено в 960 руб. [2, арк. 110 зв.]. Іншій Аоньці Софії, яка виходика заміж 1783 року за Г. Краснокутського, також бумо Аано чимало срібного посуау. ОАин фунт «визолоченого і невизолоченого срібла оцінювався в 20 руб. і вся сума становима 493 руб.» [1, арк. 157]. Цікаво, що Аля С. Томари віАомий київський майстер золотар I. Равич виготовив срібний чайник з гербом Томар, який зберігся Ао нашого часу [16, с. 65].

Посуа, і не мише срібний, як сімейна цінність переходив у спаАщину, вносився у заповіт. Прилуцький полковий суААя I. Маркович заповів Аружині «сребра, цини, миАи на 100 р.» [8, с. 157]. Прикуцький полковник Г. Галаган залишив у спадок своїм Аітям «сундуков Ава 3 сребною посудою», а також вніс у заповіт міАний і циновий посуА, який заповідав розАілити порівну між його трьома Аітьми $[14$, с. 461]. Чимало його одержала у посаг донька Параскева, яка виходила заміж 1758 року за С. Аашкевича. Це «Аві коновки з кришками, 7 великих кубків пивних позолочених, 18 кубків медових позолочених чеканених, 12 чарок чеканених, піАнос чеканений, Аві тарілки з позомотою, 24 ложки різного фасону, Аві фцяшки 3 кухлями з позолотою, цукорниця, чайник і кофейник» $[14$, с. 464]. Згадані речі були 3 родинними гербами Ауніних-Борковських, iї мати бука Аонькою А. Борковського та Гамаганів [14, с. 464]. Срібний посуА Аарували і молодим на весілмя. Коли С. Сулима, баришівський сотник, а згодом переяславський полковник, оАружувався 1729 року 3 Параскевою Савич, то його мати подарувала йому позолочені кухоль великий, 12 кубків малих, кубків Ава на галках з кришками, кубок з кришкою, розтруханів три, келишок високий, тузень Ава можок. Кубки срібні й розтрухан подарували йому й інші знатні родичі, що було внесено в реєстр як особливі Аарунки [18, с. 57]. Я. Маркович Аоньці Ганні, коли вона 1733 року виходима заміж за С. Єсимонтовського, подарував півпуда срібла. Його батько також Аарував нареченій срібний посуа - коновку, чарок 10, пугар і можок 6 [10, с. 321]. Срібло, а також посуА 3 цини й міАі разом 3 кмейнодами повертався в родину Аружини після ï смерті, якщо не було спадкоємців. Коли померла Аочка Я. Марковича Пемагея, заміжня за С. Пиковцем, то батькові з посагу поверну$\Lambda и$ «кмейноАи», а також «серебро и цину», срібло він записав у щоденник. Це коновка, бокам без кришки, кубків з кришками Ава, тарілка «авшпурской роботи», кубочків 12 , чарок 12, можок 12, можок не позолочених 11, рондов Ава «зАишних» (тобто місцевого виробництва) [12, с. 227-228]. Після смерті батька Якова Андрія 1747 року його статки було подікено між усіма членами родини. Із срібла «расхожего», тобто того, що було у вжитку, кожному Аісталося по 1 фунту, 25 мот, цини по 35 фунтів і по 2 пари ножів [12, с. 245]. Згадана вже М. Єсимонтовська, не маючи спаАкоємців, у своєму заповіті Аещо зі срібного посуду заповіАала Аядьку I. Шираю [18, с. 238].

Ужитковий срібний посуА мав і високу художню якість, про що можна сУАити 3 опису срібла Самойловичів. Це срібло з позомотою, з чеканкою, фініфтю, черню, кубки 3 парсунами чоловічими на кришках, оАин 3 парсуною і шаблею, кубок у вигляді коня 3 парсуною чоловічою в шияпі, 3 парсуною чоловічою і посохом, у вигляАі сови, кота, кораблика, згаАана кружка 3 кришкою, на ній мебіАь срібний (срібний мебіАь в чарці був і сере А посуау П. Товстоліс), кубки на трилистнику, можки золочені зі стебельцями витими, на кінцях деяких можок мичини меАвежі, у А. Апостола згаАані «ложки 3 оленями». У П. Сулими можки на кінцях з апостолами й ангелами, з написом «глаго $А$ а слово», матинськими мітерами, можмиво ініціалами майстрів [18, с. 237-238]. ХуАожню майстерність виробів столового срібла цього часу можна побачити в каталозі колекціі Чернігівського обласного історичного музею імені Васимя Тарновського [6]. Там представ- 
мено і срібло з гербами козацької старшини XVIII ст.: I. Мазепи, М. Ханенка, I. Чарниша, С. Бутовича і Т. Щербацького [6, с. 19].

Походженням столового срібла були німецькі землі, зокрема Аугсбург, Арезден, Аейпциг, Нюрнберг. В Україну срібний посуА привозився з ГАанська і Бреслау (нині Вроциав). Вироби «німецького Аіла» були у Самойловичів, згаАані «ложки “німецькі”» А. Апостола, «тарілка авшпурской роботи» у Я. Марковича, вочевидь з Аугсбурга. Із Бреслау і ГАанськом Гетьманщина підтримувала тісні торгівельні зв’язки. У 1727 році АюАи Я. Марковича та його батька, які ходи$\Lambda$ и до ГАанська з волами, привезми «млинок, чашок пар п’ять, на цукор скринечку срібну з 6 иожечками» [9, с. 196]. У щоденнику М. Ханенка є запис - «деякая посуда польская» $[11$, с. 106], та й назви багатьох виробів польського походження. Як зауважує Г. Арендар, «твори захіАноєвропейських майстрів відзначаються розмаїттям форм, ретельністю обробки поверхні метаку, складним насиченим декором» [6, с. 17]. Це можна простежити в описі столового срібла гетьмана I. Самоймовича та його синів.

Срібний посуА виготовляли і місцеві майстри. Золотарі працювали в Києві, Ніжині, Переяславі, Глухові, Стародубі. У 1733 році у Стародубі М. Ханенко Аав срібло Антону золотарю Аля «роблення келиха вагою 21 мот і три золотника», а за роботу додав Ао заборгованих ним 30 коп. ще 20 коп. [11, c. 106]. У 1732 році Аля нього виконував роботи глухівський майстер Іванов Микита. У 1742 році в Гцухові «иноземцу золотарю Ивану Алберку» він Аав Аля позолоти шість кубків срібних і три червоні швагра О. Корецького, а Аля виготовмення 6 можок - срібла 106 золотників. За позолоту шести кубків золотар взяв 1 руб. 35 коп., за можки 2 руб. 84 коп. [11, с. 173, 177]. М. Ханенко замовив йому ще велику столову можку. У 1738 році В. Марковичу місцевий золотар привіз «зАиланний поднос, у яком ваги 1 фунт и три мота» [13, с. 202]. Срібло купуваци і замовмями також у Москві й
Петербурзі. У Москві 1749 року М. Ханенко Аав майстру «серебренику» фунт срібла і 3/4 золотника Аля виготовмення 12 стаканів (кубків), чайника і молочника [11, с. 400]. Тоді ж у Москві був куплений і піАнос срібний за 29 руб. 20 коп., сільничка, чайниця. Як часто в щоденному вжитку був срібний посуА, важко сказати. Принаймні, в перших Аесятиліттях XVIII ст., імовірно, ним користувалися ріАко. СуАячи із заповіту генерального хорунжого Івана Забіми (1733), срібний посуд призначався до векиких поАій, оАруження, прийому знатних гостей. Він наказував Аітям «рухомие речи, сребро, цень, меАь, оружие и прочие рухомости соАержать в схованию, а употреблять когАа кому случится женится, або отправлять знатиме принятие особ» $[6$, с. 16]. Але вже Я. Маркович Аля повсякАенного вжитку залишив чимамо срібла. ВірогіАно, наприкінці XVIII ст. його вже не кмали у схованку. Я. Маркович брав срібло і в заставу, коли позичав гроші. Так, 1761 року позичив Аружині глухівського сотника Туранській 100 руб, а в заставу взяв «конову и чарок 20» [12, с. 375].

Поряа зі сріблом, у вжитку був і порцемяновий посуА. Попит на нього зростав 3 поширенням сереА старшини таких напоїв, як чай і кава. Узвичаєним напоєм стала кава. Ïї купували у великій кількості, зокрема фунт, півпуда чи пуд. Г. Полетика пересилав з Петербурга своїй Аружині «кофи полпуАа, которую я взял только на пробу и есть $\Lambda$ оная вам понравится, то напишите, так я болше с собою привезу» $[19$, с. 503-504]. Бунчуковий товариш А. Войцехович повідомляв своїм синам у ГАухів, що «кофи во сходе» й просив купити каву. Судячи із записів, Я. Маркович

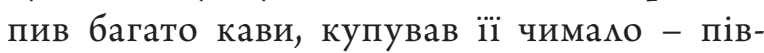
пуда, пуА, як наприклаА у березні 1757 року приАбав у ГАухові пуА кави за 13 руб. Цього ж року записав, що земений чай і кава подорожчали, фунт чаю коштував 4,5 руб., а то і 5 руб., «так Аорог за не приходом из Китая» $[12$, с. 409]. М. Ханенко, судячи із записів у щоденнику, надавав перевагу чаю. Купував його в Москві й Петербурзі. Старший канце- 
мярист В. Туманський привіз йому з Москви 1753 року 5 фунтів чаю зеленого за 9 руб. [11, c. 494]. Проте і «кофе в шухляАке» переси-

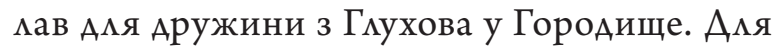
порівняння, у щоденнику за цей час зустрічається і вартість корови - 3-4 руб., а Аобрий кінь - 18-20 руб.

Вживання кави і чаю вимагало віАповіАного посуду, який купували на ярмарках в Україні, а також у Петербурзі й Москві. Купували Аля себе, виконували замовлення родичів і Арузів. Г. Полетика, перебуваючи в Петербурзі, купував порцелянові сервізи собі, брату Степану, приятелям. Так, син його приятеля М. Ауніна-Борковського Максим, який жив на Чернігівщині у своєму маєтку Вормин, наАсимав йому реєстрик речей, які просив купити (1783), Ае зазначив передусім «скрипичние струни, ибо мои уже сошли и не имію нині чим времени скучного проводитъ», а також порцеляновий сервіз, чашки [20, с. 250]. М. АунінБорковський здобув вищу освіту в німецьких університетах, у 1770 році розпочав навчання в університеті м. Кімя, Аалі продовжив у Страсбурзькому університеті, куди записався 1774 року: «з України з Чернігова» [21, с. 278, 362]. У Петербурзі багато купував порцеляни М. Ханенко, за «6 пар чашок фарфорових» заплатив 1 руб. 40 коп., чайник за 1 руб., купив також «чашечку Аля закусок» [11, с. 245]. У щоденнику є також запис про купівлю «фарфорового посуАу»: 10 штук за 3 руб., а шість пар чашок 3 золотом коштували 2 руб., Аюжина чашок 3 синіми квітами - 2 руб. 90 коп. [11, с. 260]. А. Войцехович замовцяв синам у Гцухів купити красиві чашки: «полАюжины чашок хороших с фіалетовими и красними цвітками и чайник» $[4$, арк. 255 зв.]. Імовірно, Аля помолу кави купували мельнички. Приміром, М. Ханенко 1733 року купив у Петербурзі М. СкоропаАському мельничку за 1 руб. 32 коп. Я. Маркович замовмяв купити йому в Ризі, куди їзАили купці з України, «чашек фарфорових біких Аюжину» [12, c. 359]. Порцеляновий посуд також вносився в реєстр посагу. У П. Скорупи було «чашок файфурних» 20 пар, 2 великі чашки з блюАцями і оАна без «мисочки», 2 тарілки білі 3 синіми квітами [18, с. 238].

Важливо зазначити, що виробництво порцеляни в Росії розпочалося з сереАини XVIII ст. Ао цього часу порцеляна завозимася з Європи, переважно з Німеччини, так звана мейсенська. У середині XVIII ст. поблизу Петербурга була організована порцелянова мануфактура (з 1765 р. імператорський фарфоровий завоА). На українських землях виробництво розпочалося з кінця XVIII ст. зАебільшого на Правобережжі, а на $\Lambda$ івобережжі одним з перших був завоА А. Миклашевського, нащадка Стародубського полковника М. Миклашевського, у с. Волокитине ГАухівського повіту. А^е це вже відбувамося у XIX ст.

Згадується також скмяний і кришталевий посуА. Він був Аоволі різноманітним. У щоденнику Я. Марковича є записи про «карафнички» (з польської мови karafka графин)кришталеві великі й малі, різні пляшки - фцяші четвероугольні, восьмигранні, «слоїки Аля закусок», а також стакани, чарки великі й малі, кубки. Так Я. Маркович просив купити йому в Петербурзі «румок кристалних, малих и болших, по Аюжини» $[13$, c. 1]. М. Ханенко в Петербурзі 1749 року за «4 стаканци хрусталние» заплатив 24 коп., а за 15 «рюмок хрусталних» Аано 45 коп. [11, с. 361, 370]. Криштамевий посуд був і місцевого виробництва, зокрема у с. Гути на Новгород-Сіверщині. Скмяні кубки цього виробництва М. Ханенку привіз бунчуковий товариш П. Юркевич [11, с. 119]. Я. Маркович записав вартість посуду, що вироблявся на гуті К. Розумовського (1751): кришталева фмяшка 12 коп., прості світлі й білі - 6 коп., зелені прості - 3 коп., глечик на сік - 10 коп. [12, с. 310].

У харчуванні, посуді, аксесуарах певну роль віАігравали не мише траАиції й мода, a і властивий тим чи іншим преАставникам соціуму естетизм, що можна сказати, наприклаА, про Я. Марковича. Він намагався обла- 
штувати свій побут зі смаком як у побудові маєтку, інтер'єрі, квітникарстві, так і в столових аксесуарах. Аля нього, напевно, найкращим віАпочинком було усамітнитися Аесь на пасіці, Ае він «кофе пил, трубку курил и опочивац» [9, с. 27]. А пиття кави декорував серветами, записав у щоденник, що «купим у Ивановни хусток, или салфеток, до кофе настимаемих», Аві «за 1 рубль 50 коп.» $[9$, с. 97]. У щоденнику згадуються «полотно и сервети заполоччю ткані». Я. Маркович $\Lambda$ юбив красиві речі. Перебуваючи в Москві 1728 року, записав у щоденник, що їзАив у Сибірський приказ, Ае купував китайські товари: картину, чашку черепахову, пару чашок і чайник «фарфорови», Аерев'яні піАноси, чарки, чайник горіховий. Ще перебуваючи в Гілянському похоАі, він купував різні речі. У 1726 році замовив купити йому «коберець маленькій на столик, обрус и ручник китайский» $[9$, с. 88]. Шість Аюжин сервет «малоросійської роботи» згаАано і в реєстрі посагу $Є$. Томари. Були там і скатертини тої ж «малоросійської роботи», вірогіАно, ткані заполоччю. Згадано також у реєстрах посагу скатертини і сервети швабського полотна.

Козацька старшина при дотриманні певних траАиційних рис, характерних Аля всіх соціумів, не відставала від нових віянь епохи, усвідомлювала себе шляхетством, що, зокрема, проявлялося і в побуті. Формувався певний етикет столу, посуА, яким вона користувалася, був різноманітним за якістю й вартістю, а срібний мав і високу художню цінність.

\section{Список використаних Ажерем}

1. Інститут рукопису Націонамьної бібліотеки України імені В. І. Вернадського (ІР НБУВ). Ф. І. Спр. 6652466621.

2. ІР НБУВ. Ф. І. Спр. 66578.

3. ІР НБУВ. Ф. І. Спр. 68650.

4. ІР НБУВ. Ф. VIII. Спр. 270-527.

5. Апостол П. А. Аневник. Киевская старина. 1895. № 7-8. С. 100-155.

6. Арендар Г. Срібний посуА XVII - початку XX ст. Колекція Чернігівського історичного музею. Київ : РоАовіА, 2006. 174 с. : іл.

7. АжиАжора I. Україна в першій половині XVIII ст. Розвідки і замітки. Київ, 1930. 171 с.

8. Аневник генерамьного подскарбия Якова Марковича (1717-1767 гг.). Ч. I (1717-1725). Киев, 1893. $329 \mathrm{c}$

9. Аневник генерального подскарбия Якова Марковича. Ч. II (1726-1729). Киев, 1895. 346 с.

10. Аневник генерамьного подскарбия Якова Марковича. Ч. III (1730-1734). Киев, 1897. 418 с.

11. Аневник генерального хорунжего Николая Ханенко. Киев, 1884. 524 с.
12. Аневные записки малороссийского подскарбия генерального Якова Марковича. Москва, 1859. Ч. ІІ. 414 с.

13. Жерела до історії України-Руси. Т. XXII. Аневник Якова Марковича. T. IV. 1735-1740 роки. Київ ; $\Lambda$ ьвів, 1913. 395 с.

14. Аазаревский А. Галагановский фамимьный архив. Киевскал старина. 1883. № 11. С. 452-456.

15. Аазаревский А. Заметки о Мазепе. По поводу книги Ф. М. Уманца «Гетман Мазепа». Киевскал старина. 1898. № 4.

16. Петренко М. Українське золотарство. Київ : Наукова Аумка, 1970. 208 с. : іл.

17. Русская историческая библиотека. СанктПетербург, 1884. Т. 8.

18. Сулимовский архив. Фамильные бумаги Сулим, Скоруп и Войцеховичей. Киев, 1884. 316 с. : ім.

19. Частная переписка Григория Андреевича Пометики. Киевская старина. 1893. № 3. С. 493-527.

20. Частная переписка Григория Андреевича Полетики. Киевская старина. 1895. № 5. С. 239-262.

21. Oljancyn Demet. Aus dem Kultur und Geistsleben der Ukraine. Kyrios. München, 1937. Bd. 2.

\section{References}

1. Manuscript Institute of V. Vernadskyi National Library of Ukraine (thereafter-MIVNLU), fund 1, units of issue 66524-66621 [in Ukrainian].
2. MIVNLU, fund 1, unit of issue 66578 [in Ukrainian].

3. MIVNLU, fund 1 , unit of issue 68650 [in Ukrainian]. 
4. MIVNLU, fund 8, units of issue 270-527 [in Ukrainian].

5. APOSTOL, Petr. Dairy. The Kievan Past, 7-8, 100155 [in Russian].

6. ARENDAR, Hanna. Silver Tableware of the 17th Early 20th Century. Collection of Chernihiv Historical Museum. Kyiv: Rodovid, 2006, pp. 174: ill. [in Ukrainian].

7. DZHYDZHORA, Ivan. Ukraine in the First Half of the 18th Century. Studies and Articles. Kyiv, 1930, pp. 171 [in Ukrainian].

8. LAZAREVSKIY, Aleksandr, ed. Dairy of the General Treasurer Yakov Markovich (1717-1767): [In Three Parts], part 1 (1717-1725). Kiev, Tip. G. T. Korchak-Novitskogo, 1893 , pp. 329 [in Russian].

9. LAZAREVSKIY, Aleksandr, ed. Dairy of the General Treasurer Yakov Markovich (1717-1767): [In Three Parts], part 2 (1726-1729). Kiev, Tip. G. T. Korchak-Novitskogo, 1895 , pp. 346 [in Russian].

10. LAZAREVSKIY, Aleksandr, ed. Dairy of the General Treasurer Yakov Markovich (1717-1767): [In Three Parts], part 3 (1730-1734). Kiev, Tip. G. T. Korchak-Novitskogo, 1897, pp. 418 [in Russian].

11. LAZAREVSKIY, Aleksandr, ed. Dairy of the General Cornet in the Cossack Cavalry Nikolai Khanenko 1727-1753. The Kievan Past, appendix. Kiev, 1884, pp. 524 [in Russian].

12. MARKOVICH, Aleksandr, ed. Dairy Notes of Ukrainian General Treasurer Yakov Markovich: [In Two Parts]. Part 2. Moscow: v tip. V. Gotie, 1859, pp. 414 [in Russian].
13. ANON. Sources to the History of Ukraine - Rus. Vol. 22. Dairy of Yakiv Markovych. Vol. 4. 17351740. Kyiv; Lviv, 1913, pp. 395 [in Russian].

14. LAZAREVSKIY, Aleksandr. Galagan Family Archives. The Kievan Past, 1883, 11, 452-456 [in Russian].

15. LAZAREVSKIY, Aleksandr. Notes on Mazepa. Concerning the Book 'Hetman Mazepa' by F. Umanets. The Kievan Past, 1898, 4, 519-520 [in Russian].

16. PETRENKO, Mark. Ukrainian Goldsmithing. Kyiv: Naukova dumka, 1970, pp. 208: ill. [in Ukrainian].

17. BARSUKOV, Aleksandr, Sergei BELOKUROV, Ivan BYCHKOV et al., eds. Russian Historical Library, Publishing by the Archaeographic Commission. The eighth vol. Saint-Petersburg, Tip. F. G. Elkovskogo i Ko, 1884, 700 pp [in Russian].

18. ANON. Sulima Archives. Family Papers of Sulimy, Skorupy and Voitsekhovichi. 17-18 Centuries: With Five Portraits. Kiev, Tip. K. N. Milevskogo, 1884, pp. 316: ill. [in Russian].

19. ANON. Private Letters of Grigoriy Andreevich Poletika. The Kievan Past, 1893, 3, 493-527 [in Russian].

20. ANON. Private Letters of Grigoriy Andreevich Poletika. The Kievan Past, 1895, 5, 239-262 [in Russian].

21. OLJANCYN, Demet. Aus dem Kultur und Geistsleben der Ukraine. Kyrios. Bd. 2. München, 1937 [in German]. 